This is an electronic reprint of the original article. This reprint may differ from the original in pagination and typographic detail.

Author(s): Shaikh, Aijaz A.; Karjaluoto, Heikki; Chinje, Nathalie Beatrice

Title: $\quad$ Continuous mobile banking usage and relationship commitment - A multi-country assessment

Year: $\quad 2015$

Version:

Please cite the original version:

Shaikh, A. A., Karjaluoto, H., \& Chinje, N. B. (2015). Continuous mobile banking usage and relationship commitment - A multi-country assessment. Journal of Financial Services Marketing, 20(3), 208-219. https://doi.org/10.1057/fsm.2015.14

All material supplied via JYX is protected by copyright and other intellectual property rights, and duplication or sale of all or part of any of the repository collections is not permitted, except that material may be duplicated by you for your research use or educational purposes in electronic or print form. You must obtain permission for any other use. Electronic or print copies may not be offered, whether for sale or otherwise to anyone who is not an authorised user. 


\title{
Continuous Mobile Banking Usage and Relationship Commitment - A Multi-Country
}

\section{Assessment}

\begin{abstract}
Although conducting banking transactions via mobile phones, smart phones, and tablets has become popular in many countries, major gaps exist in our understanding of those who use this technology, particularly how experienced users perceive mobile banking. Drawing from the literature on mobile banking adoption, continuous usage behavior and post-adoption of technology behavior, the authors shed light on the nature of experienced mobile banking users' relationship commitment with their bank and personal finances. The study reveals changes in commitment and shows that mobile banking offers substantial added value to users. Overall, this research will help managers better understand the importance of mobile banking services in the light of customer relationship commitment.
\end{abstract}

Keywords: Mobile banking continuous usage; Post-adoption; Finland; South Africa; Relationship commitment

\section{Introduction}

According to Forrester Research (2012), mobile channels will fundamentally change retail banking and will soon become mainstream in both developed and emerging countries. In a study of 147 countries, McKinsey and Co. (2011) argue that although mobile phones are primarily payment and information channels for people who maintain a formal bank account, 
a strategic shift now targets the unbanked, who are being offered a broad set of financial services in various countries such as in South Africa and The Philippines. Consequently, mobile banking (m-banking) has motivated banks and telecom companies to extend their commercial territory to increase revenue.

A great deal of confusion surrounds the terms "internet" and "mobile" banking. Although both are electronic banking delivery channels, internet banking (also called net-banking or online banking) is a channel for conducting transactions using a computer or a laptop (Mckinsey and Co, 2014) and normally requires a regular bank account. However, m-banking refers to banking via mobile devices including mobile phones, smart phones, and tablets that allow consumers direct access to their banking information for conducting various transactions, such as checking account information, transferring funds, paying bills, and making investments. In the past, text message (SMS) banking was the dominant m-banking financial service technology (Shaikh and Karjaluoto, 2015; Zhou et al, 2010). Today, mbanking involves several other more sophisticated technologies, such as downloadable mobile applications and the use of a mobile browser.

The m-banking framework, as depicted in Figure 1, reveals m-banking to be an integral part of mobile technology, establishing various m-banking accounts and services along with mbanking access devices and methods. Considering the two separate m-banking research streams (Shaikh and Karjaluoto, 2015), this study examines the extent of m-banking service usage in the post-adoption stage (commonly known as continuous usage behavior).

Insert Figure 1 about here 
As argued by Gupta (2013), considering the convenience of mobile devices, banks and regulators have considered $\mathrm{m}$-banking as a separate alternative delivery channel providing new opportunities for banks, convenience to customers, especially in developed countries such as Finland, and reaching a large population of unbanked customers in emerging markets, such as South Africa. Despite the huge market potential seen in the mobile-commerce market, little is known about the factors that influence the sustained use of integrated mobile financial services after adoption (Kang et al, 2012). Consequently, marketing strategy research has long emphasized the need to investigate the m-banking continuous usage context (Chen, 2012).

This study examines the consequences of m-banking services continuous usage from a relationship commitment (RC) perspective. Previous research has examined the effects of various antecedents of $\mathrm{RC}$ in the context of the business-to-business (B2B) financial services industry (Theron et al, 2008), supply chain management (Abdullah and Musa, 2014), social media (Ma and Chan, 2014), information technology services (Park et al, 2012), and ebanking (Sanchez-Franco, 2009). The majority of these studies are quantitative in nature and were conducted in a single country context (Hanafizadeh et al, 2014; Akturan and Tezcan, 2012; Zhou, 2012). Despite the availability of a substantial quantity of research in the area of information systems adoption and usage, literature dealing with experienced m-banking users from the $\mathrm{RC}$ perspective is missing. There is a growing need for research on how m-banking may be changing customer commitment to a bank as a result of less direct human interaction with the bank.

The remainder of the paper is organized as follows. The next section discusses the theoretical background of the study. The subsequent section details the research methodology. 
Thereafter, we present the analysis and results. We conclude the study with implications for academics and practitioners, the limitations of the study, and suggested directions for future research.

\section{Reasons for Continuous Usage of m-Banking and Relationship Commitment}

\subsection{Reasons for continuous usage of m-banking services}

Although a growing body of literature has highlighted the advantages and valuable aspects of mobile services including m-banking (e.g., Anckar and D'Incau, 2002; Riivari, 2005), consumers' primary reasons for adopting and using mobile services remain unclear (Meso et $a l, 2005)$, especially with respect to continuous usage. Research has revealed several factors that contribute to the usage of text-based (SMS) m-banking in Finland such as convenience, access to the service regardless of time and place, privacy, and savings in time and effort (Suoranta and Mattila, 2004; Laukkanen, 2007). In general, other factors include system quality, information quality, and interface design quality (Lee and Chung, 2009); perceived relative advantage, ease of use, compatibility, competence, and integrity (Lin, 2011). Table 1 provides a comprehensive summary of the factors contributing to m-banking usage.

\section{Insert Table 1 about here}

Perceived usefulness and perceived ease-of-use are the main determinants of m-banking usage (See Table 1). However, most of the research conducted so far has concentrated on text-based m-banking, and more developed technologies, such as mobile applications, have been almost completely neglected (Shaikh and Karjaluoto, 2015). More recently, Capgemini 
(2013) reported that customers across all segments expect highly personalized, convenient, and reliable service, along with around-the-clock accessibility. ING (2013) surveyed 12,000 people in 12 countries in Europe and found that the factors influencing the usage of $\mathrm{m}$ banking services primarily include better management and being more "in control" of money, the ability to check accounts more frequently and in real-time, and the ability to pay bills regardless of time and place.

\subsection{Relationship commitment and the financial services industry}

$\mathrm{RC}$ is one of the most frequently cited dependent variables in buyer-seller relationships in the relationship-marketing literature (Gounaris, 2005). RC refers to a pledge of continuity between partners (Dwyer et al, 1987) and a desire to maintain a relationship (Moorman et al, 1993; Morgan and Hunt, 1994). Thus, RC is a key variable in relationship marketing and keeps customers loyal regardless of instances of low satisfaction or competitive offerings. Commitment implies that there are mutual benefits, that the parties want the relationship to endure, and that the parties are prepared to incur costs to maintain the relationship and will invest effort to continue the relationship (Sharma and Patterson, 2000). Sweeney and Morrison (2003) argued that when an information technology is properly used, it can facilitate RC between the customer and the company. Similarly, Verhoef (2003) has also suggested a positive link between commitment and relationship duration (i.e., the frequency of use of services increases the customer share over time).

The relationship marketing literature recognizes two types of commitment: affective commitment and calculative commitment. The latter is also known as continuance commitment. Affective commitment refers to an emotional bond and sense of belonging 
(Delgado-Ballester and Munuera-Aleman, 2001) created through personal interaction and mutuality where the consumer is affectively committed to the service provider regardless of the type of service being used (Fullerton, 2003). Calculative commitment, in turn, refers to a situation in which a consumer has no choice but to maintain the current relationship. This calculative relationship locks the consumer into doing business with a service provider regardless of the benefits received (Fullerton, 2005).

In the financial services context, $\mathrm{RC}$ has usually been examined as an outcome variable of trust (Mukherjee and Nath, 2003; Casaló et al, 2007) and satisfaction (Verhoef, 2003). For example, studying the South African business-to-business (B2B) financial services industry, Theron et al (2008) documented the important role of RC in managing long-term marketing relationships. The authors argued that "RC can be managed by focusing on building trust between exchange partners, and by increasing the level of communication in a relationship." (p. 1007).

Other significant antecedents to $\mathrm{RC}$ in the online banking context have included the attraction of the service (Kassim and Abdulla, 2006) and shared values (Vatanasombut et al, 2008). Shared values refer to the extent to which the bank and its customers share common beliefs on critical values such as ethics, security, and privacy (Mukherjee and Nath, 2003). Vatanasombut et al (2008), additionally, find relationship termination, cost, and user (perceived) empowerment to have a significant effect on RC. Table 2 provides a comprehensive summary of empirical studies on RC in the context of financial services and information systems (IS).

Insert Table 2 about here 
With regard to affective and calculative commitment (see Table 2), affective commitment is a key determinant of word of mouth, purchase intention, and price sensitivity in the financial service industry (Bloemer and Odekerken-Schröder, 2003). Verhoef (2003) demonstrates that affective commitment has a positive influence on both retention and relationship development in terms of the share of a customer's business. Hua and Li (2010) in turn found that both types of commitment are mainly affected by the quality of alternatives, investment size and satisfaction in online travel context. However, opposing views have also been presented. Lewis and Soureli (2006), for example, found no correlation between affective commitment and loyalty in the online banking context.

Some synergy between RC and banking technology infrastructure also emerged from a few studies that report that improved infrastructure significantly affects the degree of satisfaction of consumers and is, thus, an important variable for m-banking environments. Specifically, mobile technology infrastructure relies on the integration of wireless and internet technologies (Luo et al, 2010), and m-banking adoption and usage varied across markets due to differences in countries' economic, regulatory, and banking infrastructure (Gupta, 2013). In this vein, Raassen et al (2014) argued that emerging markets are characterized by less effective regulatory and enforcement mechanisms, while established economies are governed by more formal and transparent rules and restrictions. To achieve consumer commitment, a company's strategy must be consumer centric, long term, and based on mutual relationship benefits (Adamson et al, 2003). Thus, the stronger the level of consumer commitment to a service provider, the less likely it is that either relationship partner will voluntarily dissolve the relationship (Hocutt, 1998).

\section{Methodology}


As m-banking is a relatively new area of research (e.g., Cruz et al, 2010), a qualitative approach using one-on-one in-depth semi-structured interviews was chosen. Interviews were chosen as the primary data collection method, as they provide a deeper understanding of the phenomenon and previous research has demonstrated their feasibility in studying innovative mobile services (Jarvenpaa and Lang, 2005). In total, 36 in-depth interviews were conducted with experienced m-banking users, including professionals and students, in the city of Jyväskylä (Finland-FIN) and Johannesburg (South Africa-SA). A purposeful sampling technique was used in which the participants were selected according to the needs of the study (Morse, 1991, p. 129), in our case on the basis of their m-banking experience (minimum six months). Thus, this sample has the ability to contribute to the theoretical understanding of the subject of the study (Bryman and Bell, 2011, p. 500). Interviews were conducted in a semi-structured format that allowed participants to express their own viewpoints. An interview guide that broadly outlined the topics of interest of the study was used. The interviews were designed to reveal the personal meanings respondents relate to the terms m-banking usage and RC. Thus, the objective was to collect reflections from the respondents and to discover various factors that arose from the terms m-banking continuous usage and commitment. Locations for the interviews were carefully selected in each country to ensure they offered a quiet spot for the researcher to record the interview.

A directed approach to qualitative content analysis was applied (Hsieh and Shannon, 2005). In analyzing the data, researchers followed a three-step process of data reduction, data display, and verification (Miles and Huberman, 1984). In the first stage, considering the purpose of this study, the transcriptions were organized to reveal anticipated factors related to reasons for using $\mathrm{m}$-banking and $\mathrm{RC}$. The data analysis began after the first interviews. This 
method helped the researchers to plan and direct the ensuing interviews. In the second phase, these factors were analyzed individually. We also verified the data by sending the transcribed data and results of the study to the interviewees and inviting their comments. Finally, the interviewees' comments were incorporated where appropriate.

\subsection{Sample}

The sample was male dominated (64\%). The majority of the respondents $(86 \%)$ were working professionals. Approximately half of those interviewed (53\%) were between 25 and 32 years old. Two-thirds of the respondents $(67 \%)$ had more than two years of experience with m-banking services, and only a few (17\%) had less than one year of experience. The demographic profile of the sample is shown in Table 3.

Insert Table 3 about here

Smartphones proved to be the main portable device used to access m-banking services both in FIN and SA and were used by more than two-thirds (64\%) of the participants, while only a few $(11 \%)$ solely used tablet PCs. One fourth of the participants used both devices to conduct their m-banking transactions. Various data transmission technologies were used to access m-banking services. SMS in SA and mobile applications provided by the bank in FIN were the prominent m-banking technologies used.

\section{Results}

\subsection{Reasons for continuous usage of m-banking services}


The most discussed reason for using m-banking services on a continuous basis was convenience. Respondents in both FIN and SA revealed that in addition to convenience of use, freedom of location and time, user-friendliness of the m-banking services and the application were important. Although the respondents in SA further revealed that they preferred to use m-banking over other delivery channels, such as internet banking (via PC), this result was less prevalent among FIN respondents. Other reasons for using m-banking services included speed, usefulness, and improved control over the user's bank account. A few of the respondents reported that m-banking was more convenient than online banking, while others emphasized the convenience of being able to check their financial affairs in real time, anywhere, and at any time. Convenience was commonly described in the following way:

It (m-banking) has made banking more convenient. I have more control of my account than in the past. So, that is the value that I get out of it. It is convenient; it feels like I get a little more control (Anthony, SA).

Absolutely, m-banking services have made my life easy. Whatever and whenever I want to use and access my account, I can do it without any difficulty and also from outside Finland (Merja, FIN).

Convenience when you wake up in the morning and you just go onto your phone and you can do a payment to a third party anywhere in the world. So, it is very convenient for me personally (Sidra, SA). 
I feel that I am getting close to my account. M-banking service is a little bit easier and therefore it makes me little (more) happier with my bank. It helps a lot. It gives me an opportunity to check my account in real time, my funds and everything (Mikko, FIN).

The study participants differentiated between the 'financial' and the 'non-financial' services they access through mobile devices. The prominent financial services, for example, included fund transfers, bill payments, and investment transactions. Non-financial services included balance enquiry and receiving service notifications. A divergence in the opinions of the respondents was also noted when checking their level of satisfaction and convenience of using m-banking services and applications. Here, a few tech-savvy respondents in SA and many in FIN explicitly emphasized the quality of an m-banking application as a major motivation source for continuously using m-banking services. These respondents found $\mathrm{m}$ banking applications contextual and potentially entertaining and preferred to use them in the future.

I've got the m-banking App on my phone, it's easy, very easy, and I log-in regularly. It keeps me up to date, I can pay people who I forgot to pay, and I'm not restricted to banking hours (Sindhu, SA).

In sum, consumer motivation to use m-banking is primarily associated with convenience of use, freedom of location and time, and the user-friendly nature.

\subsection{M-banking and relationship commitment}


Our second research question focuses on the nature of experienced mobile banking continuous users' RC with their bank and personal finances. The findings reveal several important factors related to the concept of commitment and its object: whether it is commitment to a bank or to the management of personal finances and the channel itself (mobile):

It depends on how you see commitment to my bank. If it's interacting with my account, I am more committed, and if it is dealing with the people at the bank, I am less committed. So, I don't really see the people at the bank, but I deal with the (mobile) app a lot. However, dealing with the people at the bank doesn't necessarily make the experience better (Inu, FIN).

Overall, as the use of m-banking has reduced visits to bank branches in both FIN and SA and because of the convenience and speed attached to m-banking, customers can now access their accounts at any time and from anywhere. This reflects changes in the respondents' commitment to the bank but more importantly to the perceptions of how they manage their personal banking affairs. The majority of the respondents (67\%) in FIN and SA agreed that their commitment to their bank increased after using m-banking services:

My commitment to the bank has increased after using the m-banking services because mbanking services are very easy to use, and I can access my bank account wherever and whenever I want (Minna, FIN).

M-banking services have increased my commitment to my mobile device but [have] substantially decreased my visits to my bank. I can check my bank statements, balance history, do transactions, block cards...so, there is no need to go to the bank (Henry, SA). 
The remaining respondents (33\%) thought that there had been little or no change in their commitment to the bank itself after using m-banking services but an increase in the commitment to the management of personal finances. The results clearly reveal that commitment is affective in nature, as it reflects emotional issues related to the feeling of being in more control over personal finances:

I have a wild dream that one day everything may be available on cell phones. I mean IDs, debit cards, credit cards, virtually everything (Aleena, FIN).

Although I am highly committed to the bank, my commitment has not been affected since using m-banking services. My bank always listens and cares for its customers (Anders, FIN).

Yes, I think definitely more committed. There is the online share trading, there's opening investment accounts, and that sort of thing, which I have done, and it makes it easier by having a mobile platform to do that and by not having to go into the bank to set it up; it makes it a lot easier, whereas if you wanted to buy shares in the past, you had to go and see a broker, you got to go and look at things, and you got to just to a certain extent learn about things or you got to pay a high fee. Now, with having all these electronic services sort of at your fingertips, it makes life easier, you can - I mean again, it's a sales tool from the bank, the more that they can give you access to, the more that you are going to involve with them and spend (Richard, SA).

Our results reveal important differences among the two markets examined (FIN and SA). Overall, the respondents in FIN were less dependent on m-banking services than those in SA 
and were more affectively committed towards their bank. This result occurred because all of the Finnish respondents used online banking services as well, whereas in SA, online banking was not frequently used. The results also suggest that consumers in FIN see m-banking primarily as a supplement rather than as a substitute for online banking.

Almost all of the respondents expressed their intention to continue using m-banking services in the future. One respondent in FIN described his feelings by saying that "If you do not offer m-banking services, you are silly." These arguments support the notion that the use of mbanking services in the future will increase the overall market for m-banking services both in mature and emerging markets. This study has also recorded the expectations of the respondents of m-banking services because these expectations might affect their decisions to continuously use the services in the future. As described by one respondent:

Yes, m-banking has become a necessity. If taken away, I will miss it. Banks must listen to customers' needs so that they can provide their customers what they need. Banks can offer online chat services on m-banking applications (Dayan, SA).

\section{Conclusion}

Relationship commitment is crucial in banking, a finding already known from previous research (e.g., Aurier and N'Goala, 2010). This research broadens our understanding of continuous usage of m-banking services in the context of $\mathrm{RC}$. The study is a response to the call for more in-depth, customer-oriented research on the use of m-banking services (Shaikh and Karjaluoto, 2015; Kang et al, 2012; Chen, 2012). 
The study contributes to the literature on m-banking in different ways. First, we contribute to the theory of m-banking adoption and use (Shaikh and Karjaluoto, 2015) by showing insights into the drivers of continuous usage of m-banking services. We find that the main motivation for continuous usage is convenience. Second, we shed light on the m-banking users' continuous usage behavior by addressing the issue of how the use of the mobile channel in retail banking affects the customer-bank relationship from a commitment perspective (AlHawari et al, 2009; Casaló et al, 2007; Vatanasombut et al, 2008). Specifically, our findings reveal that consumer perceptions of their commitment to the management of their personal finances have changed due to the utilization of m-banking services. Overall, the results indicate positive changes in bank customers' commitment after using m-banking services.

The main strategic implication of our research for managers is that m-banking should be treated as a vital new delivery channel in retail banking. This suggests that all players in the field should take the development of m-banking services seriously. We recommend two strategies. First, the existing system, that is, a universal m-banking application with extensive features for all is most likely not the best solution to provide m-banking services. Instead, we recommend following the example offered by the Austrian bank Raiffeisen, which has a tailored m-banking application for students (i.e. Raiffeisen Club) and developed tailored mbanking services to better serve the needs of different customer segments. This personalization could then produce enhanced commitment to the bank and better management of personal finances. Second, we suggest that financial service providers improve the features of their m-banking applications for various customer segments to provide better two-way communication. In many other sectors, mobile applications make use of the most powerful features of mobile channels, such as context (including time and place), 
that are currently missing in most m-banking applications. An exception is the Raiffeisen example.

The study has some limitations that might be addressed in future studies. First, the study is exploratory and qualitative in nature. Thus, wider generalizations of the findings cannot be made. Second, the study is not longitudinal and does not therefore capture the full dynamism of continuous usage behavior. Future research might therefore adopt a longitudinal approach to study continuous usage behavior and its effects on bank-customer relationships. By doing so, researchers could test the causal effects of RC on relationship development.

\section{References}

Abdullah, Z. and Musa, R. (2014) The effect of trust and information sharing on relationship commitment in supply chain management. Procedia-Social and Behavioral Sciences 130: 266-272.

Adamson, I., Chan, K. M. and Handford, D. (2003) Relationship marketing: customer commitment and trust as a strategy for the smaller Hong Kong corporate banking sector. International Journal of Bank Marketing 21(6): 347-358.

Akturan, U. and Tezcan, N. (2012) Mobile banking adoption of the youth market: Perceptions and intentions. Marketing Intelligence and Planning 30(4): 444-459. 
Alafeef, M., Singh, D. and Ahmad, K. (2011) Influence of demographic factors on the adoption level of mobile banking applications in Jordan. Research Journal of Applied Sciences 6(6): 373-377.

Al-Hawari, M., Ward, T. and Newby, L. (2009) The relationship between service quality and retention within the automated and traditional contexts of retail banking. Journal of Service Management 20(4): 455-472.

Al-Jabri, I. M. and Sohail, M. S. (2012) Mobile banking adoption: application of diffusion of innovation theory. Journal of Electronic Commerce Research 13(4): 379-391.

Anckar, B. and D'Incau, D. (2002) Value creation in mobile commerce: findings from a consumer survey. Journal of Information Technology Theory and Application 4: 43-64.

Aurier, P. and N'Goala, G. (2010) The differing and mediating roles of trust and relationship commitment in service relationship maintenance and development. Journal of the Academy of Marketing Science 38(3): 303-325.

Bloemer, J. and Odekerken-Schröder, G. (2003) Antecedents and consequences of affective commitment. Australasian Marketing Journal 11(3): 33-43.

Bryman, A. and Bell, E. (2011) Business Research Methods, 3rd ed. Oxford: Oxford University Press. 
Caceres, R.C. and Paparoidamis, N. G. (2007) Service quality, relationship satisfaction, trust, commitment and business-to-business loyalty. European Journal of Marketing 41(7/8): 836867.

Capgemini (2013) Trends in retail banking channels: Meeting changing client preferences.

Capgemini report, 22 April,

http://www.capgemini.com/sites/default/files/resource/pdf/trends_in_retail_banking_channels _meeting_changing_client_preferences.pdf, accessed 28 October 2014.

Casaló, L.V., Flavián, C. and Guinalíu, M. (2007) The role of security, privacy, usability and reputation in the development of online banking. Online Information Review 31(5): 583-603.

Chemingui, H. (2013) Resistance, motivations, trust and intention to use mobile financial services. International Journal of Bank Marketing 31(7): 574-592.

Chen, S.C. (2012) To use or not to use: Understanding the factors affecting continuance intention of mobile banking. International Journal of Mobile Communications 10(5): 490507.

Cruz, P., Neto, L. B. F., Muñoz-Gallego, P. and Laukkanen, T. (2010) Mobile banking rollout in emerging markets: evidence from Brazil. International Journal of Bank Marketing, 28(5): $342-371$.

Delgado-Ballester, E. and Munuera-Aleman J.L. (2001) Brand trust in the context of consumer loyalty. European Journal of Marketing 35(11/12): 1238-1258. 
Dwyer, F. R., Schurr, P.H. and Oh, S. (1987) Developing buyer-seller relationships. Journal of Marketing 51(2): 11-27.

Forrester Research (2012) The state of mobile banking 2012. Forrester Research report, 13 August, http://www.miteksystems.com/files/mitek/docs/the_state_of_mobile_banki.pdf, accessed 1 October 2014.

Fullerton, G. (2005) How commitment both enables and undermines marketing relationships? European Journal of Marketing 39(11/12): 1372-1388.

Fullerton, G. (2003) When does commitment lead to loyalty? Journal of Service Research 5 (4), 333-344.

Gounaris, S. P. (2005) Trust and commitment influences on customer retention: Insights from business-to-business services. Journal of Business Research 58(2): 126-140.

Gu, J.C., Lee, S.C. and Suh, Y.H. (2009) Determinants of behavioral intention to mobile banking. Expert Systems with Applications 36(9): 11605-11616.

Gupta, S. (2013) The mobile banking and payment revolution. European Financial Review February-March: 3-6.

Hanafizadeh, P., Behboudi, M., Abedini K.A. and Jalilvand S.T.M. (2014) Mobile-banking adoption by Iranian bank clients. Telematics and Informatics 31(1): 62-78. 
Hocutt, M.A. (1998) Relationship dissolution model: antecedents of relationship commitment and the likelihood of dissolving a relationship. International Journal of Service Industry Management 9(2): 189-200.

Hsieh, H.F. and Shannon, S.E. (2005) Three approaches to qualitative content analysis. Qualitative Health Research 15(9): 1277-1288.

Hua, N. and Li, X. (2010) A conceptual framework of relationship commitment: e-travel agencies. Journal of Hospitality and Tourism Technology 1(2): 106-120.

ING (2013) Financial empowerment in the digital age, ING international survey report, 1 July, http://www.ezonomics.com/ing_international_survey/mobile_banking_2013, accessed 28 October 2014.

Jarvenpaa, S.L. and Lang, K.R. (2005) Managing the paradoxes of mobile technology. Information Systems Management 22(4): 7-23.

Kang, H., Lee, M.J. and Lee, J.K. (2012) Are you still with us? A study of the post-adoption determinants of sustained use of mobile-banking services. Journal of Organizational Computing and Electronic Commerce 22(2): 132-159.

Kassim, N.M. and Abdulla, A.K.M.A. (2006) The influence of attraction on internet banking: an extension to the trust-relationship commitment model. International Journal of Bank Marketing 24(6): 424-442. 
Laukkanen, T. (2007) Internet vs mobile banking: comparing customer value perceptions. Business Process Management Journal, 13(6): 788-797.

Lee, K. C. and Chung, N. (2009) Understanding factors affecting trust in and satisfaction with mobile banking in Korea: A modified DeLone and McLean's model perspective. Interacting with Computers 21(5): 385-392.

Lewis, B.R. and Soureli, M. (2006) The antecedents of consumer loyalty in retail banking. Journal of Consumer Behaviour 5(1): 15-31.

Lin, H.F. (2011) An empirical investigation of mobile banking adoption: the effect of innovation attributes and knowledge-based trust. International Journal of Information Management 31(3): 252-260.

Luo, X., Li, H., Zhang, J. and Shim, J. P. (2010) Examining multi-dimensional trust and multi-faceted risk in initial acceptance of emerging technologies: An empirical study of mobile banking services. Decision Support Systems 49(2): 222-234.

Ma, W.W. and Chan, A. (2014) Knowledge sharing and social media: Altruism, perceived online attachment motivation, and perceived online relationship commitment. Computers in Human Behavior 39: 51-58.

McKinsey and Co. (2011) What's the future of mobile banking in Europe? McKinsey \& Co article, October, http://www.mckinsey.com/insights /financial_services/whats_the_future_of _mobile_banking_in_europe, accessed 15 October 2014. 
McKinsey and Co. (2014) The rise of the digital bank, McKinsey \& Co article, July http://www.mckinsey.com/insights/business_technology/the_rise_of_the_digital_bank, accessed 15 October 2014.

Meso, P., Musa, P. and Mbarika, V. (2005) Towards a model of consumer use of mobile information and communication technology in LDCs: the case of sub-Saharan Africa, Information Systems Journal 15: 119-146.

Miles, M.B. and Huberman, A.M. (1984) Drawing valid meaning from qualitative data: Toward a shared craft. Educational Researcher 13(5): 20-30.

Moorman, C., Deshpandé, R. and Zaltman, G. (1993) Factors affecting trust in market relationships. Journal of Marketing 57(1): 81-101.

Morgan, R.M. and Hunt, S.D. (1994) The commitment-trust theory of relationship marketing. Journal of Marketing 58(3): 20-38.

Morse J.M. (1991) Strategies for sampling. In J.M. Morse (ed.) Qualitative Nursing Research: A Contemporary Dialogue. Newbury Park, California: Sage, pp. 127-145.

Mukherjee, A. and Nath, P. (2003) A model of trust in online relationship banking. International Journal of Bank Marketing 21(1): 5-15. 
Nel, J., Boshoff, C. and Raleting, T. (2012) Exploiting the technology cluster effect to enhance the adoption of WIG mobile banking among low-income earners. Management Dynamics: Journal of the Southern African Institute for Management Scientists 21(1): 30-44.

N'Goala, G. (2007) Customer switching resistance (CSR): the effects of perceived equity, trust and relationship commitment. International Journal of Service Industry Management 18(5): 510-533.

Park, J., Lee, J., Lee, H. and Truex, D. (2012) Exploring the impact of communication effectiveness on service quality, trust and relationship commitment in IT services. International Journal of Information Management 32(5): 459-468.

Raassen, N., Wuyts, S. and Geyskens, I. (2014) The performance implications of outsourcing customer support to service providers in emerging versus established economies. International Journal of Research in Marketing 31(3): 280-292.

Ravindran, D.S. (2012) An empirical study on service quality perceptions and continuance intention in mobile banking context in India. Journal of Internet Banking and Commerce 17(1): 1-22.

Riivari, J. (2005) Mobile banking: a powerful new marketing and CRM tool for financial services companies all over Europe. Journal of Financial Services Marketing 10(1), 11-20. 
Safeena, R., Date, H., Kammani, A. and Hundewale, N. (2012) Technology adoption and Indian consumers: Study on mobile banking. International Journal of Computer Theory and Engineering 4(6): 1020-1024.

Sanchez-Franco, M.J. (2009) The moderating effects of involvement on the relationships between satisfaction, trust and commitment in e-banking. Journal of Interactive Marketing 23(3): 247-258.

Shaikh, A.A. and Karjaluoto, H. (2015) Mobile banking adoption: A literature review. Telematics and Informatics 32(1): 129-142.

Sharma, N. and Patterson, P. G. (2000) Switching costs, alternative attractiveness and experience as moderators of relationship commitment in professional, consumer services. International Journal of Service Industry Management 11(5): 470-490.

Sharma, N. and Patterson, P. G. (1999) The impact of communication effectiveness and service quality on relationship commitment in consumer, professional services. Journal of Services Marketing 13(2): 151-170.

Suoranta, M. and Mattila, M. (2004) Mobile banking and consumer behavior: new insights into the diffusion pattern. Journal of Financial Services Marketing 8(4): 354-366.

Sweeney, A. and Morrison, M. (2003) Clicks vs. bricks: internet-facilitated relationships in financial services. International Journal of Internet Marketing and Advertising 1(4): 350-370. 
Teo, A.C., Tan, G.W.H., Cheah, C.M., Ooi, K.B. and Yew, K.T. (2012) Can the demographic and subjective norms influence the adoption of mobile banking? International Journal of Mobile Communications 10(6): 578-597.

Theron, E., Terblanche, N. S. and Boshoff, C. (2008) The antecedents of relationship commitment in the management of relationships in business-to-business (B2B) financial services. Journal of Marketing Management 24(9-10): 997-1010.

Vatanasombuta, B., Igbaria, M., Stylianou, A.C. and Rodgers, W. (2008) Information systems continuance intention of web-based applications customers: The case of online banking. Information \& Management 45(7), 419-428.

Verhoef, P.C. (2003) Understanding the effect of customer relationship management efforts on customer retention and customer share development. Journal of Marketing 67(4): 30-45.

Yu, C.S. (2012) Factors affecting individuals to adopt mobile banking: Empirical evidence from the UTAUT model. Journal of Electronic Commerce Research 13(2): 104-121.

Zhao, X., Huo, B., Flynn, B. B. and Yeung, J. H. Y. (2008) The impact of power and relationship commitment on the integration between manufacturers and customers in a supply chain. Journal of Operations Management 26(3): 368-388.

Zhou, T. (2011) An empirical examination of initial trust in mobile banking. Internet Research 21(5): 527-540. 
Zhou, T. (2012) Examining mobile banking user adoption from the perspectives of trust and flow experience. Information Technology and Management 13(1): 27-37.

Zhou, T., Lu, Y. and Wang, B. (2010) Integrating TTF and UTAUT to explain mobile banking user adoption. Computers in Human Behavior 26(4): 760-767. 